\title{
Breast augmentation: A geographical comparison
}

\author{
Janae L Maher MD¹, Della C Bennett MD², Laura L Bennett MD³, Peter Grothaus MD³, Raman C Mahabir MD
}

\author{
JL Maher, DC Bennett, LL Bennett, P Grothaus, RC Mahabir. \\ Breast augmentation: A geographical comparison. Can J Plast Surg \\ 2010;18(4):e44-e46.
}

OBJECTIVE: To describe and compare physical characteristics and implant details of women undergoing primary cosmetic breast augmentation in different geographical locations.

METHODS: Three cohorts of 100 consecutive breast augmentation cases in university settings were retrospectively reviewed for patient demographic and implant information in Kelowna (British Columbia), Loma Linda (California, USA) and Temple (Texas, USA). Statistical analysis was performed with a Kruskal-Wallis test without normality assumption $(\mathrm{P}<0.05$ was considered to be significant). Pearson correlation coefficients were also determined for body mass index (BMI) versus implant volume at each of the sites.

RESULTS: The three group medians were significantly different for weight, BMI and implant volume. Kelowna's average patient was 33 years of age, had a BMI of $20.8 \mathrm{~kg} / \mathrm{m}^{2}$ and an implant volume of $389 \mathrm{~mL}$. Loma Linda's average patient was 32 years of age, had a BMI of $21.6 \mathrm{~kg} / \mathrm{m}^{2}$ and an implant volume of $385 \mathrm{~mL}$. Temple's average patient was 36 years of age, had a BMI of $22.6 \mathrm{~kg} / \mathrm{m}^{2}$ and an implant volume of $335 \mathrm{~mL}$. Pearson correlations for BMI versus implant volume were statistically significant in the Loma Linda and Temple groups.

CONCLUSION: Patients from different geographical locations undergoing breast augmentation were similar in age, height and parity, but varied in weight, BMI and implant volume. A positive linear correlation between $\mathrm{BMI}$ and implant volume was found in the American cohorts.

Key Words: Body mass index; Breast augment; Implant volume

$\mathrm{C}$ urrent estimates of the number of women in North America with breast implants range from one to two million, representing $1 \%$ of the adult female population (1-3). Procedural statistics from the American Society of Plastic Surgeons reported that more than 300,000 breast augmentations were performed in 2008 . This correlates to a $45 \%$ increase in women seeking breast augmentation since 2000, making it now the single most common cosmetic surgical procedure in the United States (4). Demographics for this increasing plastic surgery patient population have not often been described in the literature. The purpose of the present study was to report and compare physical characteristics and implant details of women undergoing primary cosmetic breast augmentation in different geographical locations.

\section{METHODS}

Three cohorts of 100 consecutive breast augmentation cases were retrospectively reviewed from a four-physician practice in Kelowna, British Columbia; a five-physician practice in Loma Linda, California, USA; and a five-physician practice in Temple, Texas, USA. All three practices were university

\section{L'augmentation mammaire : Une comparaison géographique}

OBJECTIF : Décrire et comparer les caractéristiques physiques et les détails des implants des femmes qui subissent une augmentation mammaire esthétique primaire dans divers lieux géographiques.

MÉTHODOLOGIE: Trois cohortes de 100 cas consécutifs d'augmentations mammaires effectuées en milieu universitaire ont fait l'objet d'un examen rétrospectif afin de déterminer la démographie des patientes et l'information relative aux implants à Kelowna (Colombie-Britannique), à Loma Linda (Californie, États-Unis) et à Temple (Texas, États-Unis). Les chercheurs ont procédé à l'analyse statistique au moyen d'un test de Kruskal-Wallis sans hypothèse de normalité ( $\mathrm{P}<0,05$ était jugé comme significatif). Ils ont également déterminé les coefficients de corrélation de Pearson à l'égard de l'indice de masse corporelle (IMC) par rapport au volume des implants à chacun des lieux géographiques.

RÉSULTATS : Les médianes des trois groupes étaient considérablement différentes en matière de poids, d'IMC et de volume d'implants. La patiente moyenne de Kelowna avait 33 ans, un IMC de $20,8 \mathrm{~kg} / \mathrm{m}^{2}$ et un volume d'implants de $389 \mathrm{~mL}$. La patiente moyenne de Loma Linda avait 32 ans, un IMC de 21,6 kg/m $\mathrm{m}^{2}$ et un volume d'implants de $385 \mathrm{~mL}$. Enfin, la patiente moyenne de Temple avait 36 ans, un IMC de $22,6 \mathrm{~kg} / \mathrm{m}^{2}$ et un volume d'implants de $335 \mathrm{~mL}$. Les corrélations de Pearson dans les IMC par rapport au volume d'implants étaient statistiquement significatives à l'égard des groupes de Loma Linda et de Temple.

CONCLUSION : Des patientes de divers lieux géographiques qui subissent une augmentation mammaire avaient un âge, une taille et une parité similaires, mais un poids, un IMC et un volume d'implants différents. On a constaté une corrélation linéaire positive entre l'IMC et le volume d'implants dans les cohortes des États-Unis.

based/affiliated. Data were gathered and compared regarding height, weight, body mass index (BMI), age, parity and implant volume. Statistical analysis was performed with a Kruskal-Wallis test without normality assumption; $\mathrm{P}<0.05$ was considered to be statistically significant. Pairwise comparison with Bonferroni adjustment was performed. For pairwise comparison, $\mathrm{P}<0.016(0.05 / 3=0.016)$ was considered to be statistically significant. Pearson correlation coefficients were also determined for BMI versus implant volume at each site.

\section{RESULTS}

The results are presented in Table 1. Kelowna's average patient was 33 years of age with a height of $165 \mathrm{~cm}$, weight of $56.2 \mathrm{~kg}$ (BMI of $20.8 \mathrm{~kg} / \mathrm{m}^{2}$ ) and parity of 1.7 ; the average implant volume was $389 \mathrm{~mL}$. Loma Linda's average patient was 32 years of age with a height of $162 \mathrm{~cm}$, weight of $58.5 \mathrm{~kg}$ (BMI of $21.6 \mathrm{~kg} / \mathrm{m}^{2}$ ) and parity of 1.9 ; the average implant volume was $385 \mathrm{~mL}$. Temple's average patient was 36 years of age with a height of $163 \mathrm{~cm}$, weight of $59.9 \mathrm{~kg}\left(\mathrm{BMI}\right.$ of $\left.22.6 \mathrm{~kg} / \mathrm{m}^{2}\right)$ and parity of 1.7; the average implant volume was $335 \mathrm{~mL}$.

${ }^{1}$ Department of Plastic Surgery, Scott and White Memorial Hospital, Temple, Texas; ${ }^{2}$ Department of Plastic and Reconstructive Surgery,

Loma Linda University, School of Medicine, Loma Linda, California; ${ }^{3}$ Image Sculptors, Abilene, Texas, USA

Correspondence: Dr Raman C Mahabir, Division of Plastic Surgery, Scott Eु White - Texas A Eु M, 2401 S 31st, Temple, Texas 76508, USA.

Telephone 254-493-3690, e-mail rmahabir@swmail.sw.org 
TABLE 1

Cosmetic breast augmentation patient demographics and details

\begin{tabular}{|c|c|c|c|c|}
\hline Variable & $\begin{array}{c}\text { Kelowna, } \\
\text { British } \\
\text { Columbia } \\
\text { (mean } \pm \text { SD) }\end{array}$ & $\begin{array}{c}\text { Loma Linda, } \\
\text { California, USA } \\
\text { (mean } \pm \text { SD) }\end{array}$ & $\begin{array}{c}\text { Temple, } \\
\text { Texas, USA } \\
\text { (mean } \pm \text { SD) }\end{array}$ & $\mathbf{P}$ \\
\hline Age, years & $33 \pm 8$ & $32 \pm 10$ & $36 \pm 12$ & 0.0671 \\
\hline Height, cm & $165 \pm 8$ & $163 \pm 8$ & $163 \pm 8$ & 0.1282 \\
\hline Weight, kg & $56.2 \pm 7$ & $58.5 \pm 9$ & $59.9 \pm 10$ & $0.0203^{\star}$ \\
\hline BMI, $\mathrm{kg} / \mathrm{m}^{2}$ & $20.8 \pm 2.0$ & $21.6 \pm 2.7$ & $22.6 \pm 3.3$ & $<0.0001^{*}$ \\
\hline Parity, n & $1.7 \pm 1.4$ & $1.9 \pm 1.6$ & $1.7 \pm 1.3$ & 0.7276 \\
\hline $\begin{array}{c}\text { Average implant } \\
\text { volume, } \mathrm{mL}\end{array}$ & $389 \pm 80$ & $385 \pm 91$ & $335 \pm 77$ & $<0.0001^{*}$ \\
\hline
\end{tabular}

${ }^{*} P<0.05$. BMI Body mass index

Of the demographic information, the three group medians were significantly different for weight, BMI and implant volume. Table 1 shows that the lowest average BMI was in Kelowna. Pairwise comparison showed that this was significantly lower than in either of the other sites $(\mathrm{P}<0.0001$; Table 2$)$. The smallest average implant volumes were found in Temple and these were also found, by pairwise comparison, to be significantly lower $(\mathrm{P}<0.0001)$ than either of the other sites.

When considering the 300 patients as one cohort, the average patient age was 34 years of age with a height of $163 \mathrm{~cm}$, weight of $58.1 \mathrm{~kg}$ (BMI of $\left.21.7 \mathrm{~kg} / \mathrm{m}^{2}\right)$ and parity of 1.7 ; the average implant volume was $370 \mathrm{~mL}$.

The correlation of BMI versus implant volume at each cohort site was also investigated (Figure 1). Pearson correlation coefficient determined a statistically significant positive correlation between BMI and implant volume in the patient populations at Loma Linda (correlation $=0.5386 ; \mathrm{P}<0.0001$ ) and Temple (correlation $=0.3604 ; \mathrm{P}=0.0002$ ). A positive correlation trend was also observed in the patient group from Kelowna; however, this was not statistically significant (correlation $=0.1677 ; \mathrm{P}=0.0953$ ).

\section{DISCUSSION}

The average age of women undergoing augmentation in our study was 34 years (range 16 to 72 years). Similar ages at the time of surgery have been reported from Pennsylvania, Texas, and Washington (USA) (5-7). It appears that age at the time of implantation is similar throughout North America. In Europe, this may not be the case. In a large $(n=1369)$ Swedish series (8), the average age at the time of surgery was 44 years, while in Denmark $(\mathrm{n}=754)$, it was 32 years (9).

Height, weight, BMI and the number of children are often reported as grouped data (ie, less than 55,55 to 60 , etc), not averages, in the literature. In an available study in which averages were reported (5) $\left(168 \mathrm{~cm}, 58.5 \mathrm{~kg}, \mathrm{BMI}\right.$ of $\left.21.4 \mathrm{~kg} / \mathrm{m}^{2}\right)$, they were similar to our average height of $162 \mathrm{~cm}$, weight of $58.5 \mathrm{~kg}$ and BMI of $21.7 \mathrm{~kg} / \mathrm{m}^{2}$. For the number of offspring, the reported average of 1.8 children (10) was also similar to our average of 1.7 children.

The average implant volume was $370 \mathrm{~mL}$. The literature on average implant volume is scarce for studies with more than 50 cases. In fact, only two could be located through a PUBMED/ OVID literature search (using the terms "implant fill", "implant volume" and "implant size"). The average implant size in those studies was $247 \mathrm{~mL}$ in Denmark (9) and $270 \mathrm{~mL}$ in the United
TABLE 2

Pairwise comparison with Bonferroni adjustment

\begin{tabular}{lccc}
\hline Variable & $\begin{array}{c}\text { Temple versus } \\
\text { Kelowna }\end{array}$ & $\begin{array}{c}\text { Temple versus } \\
\text { Loma Linda }\end{array}$ & $\begin{array}{c}\text { Kelowna versus } \\
\text { Loma Linda }\end{array}$ \\
\hline Age, years & 0.068 & 0.038 & 0.540 \\
Height, cm & 0.061 & 0.707 & 0.119 \\
Weight, kg & 0.007 & 0.239 & 0.096 \\
Body mass index, & $<0.001$ & 0.054 & $0.008^{*}$ \\
kg/m ${ }^{2}$ & & & 0.432 \\
Parity, n & 0.743 & 0.620 & 0.888 \\
Average implant & $<0.001^{*}$ & $<0.001^{*}$ & \\
volume, mL & & & \\
${ }^{*} P<0.016$ & &
\end{tabular}

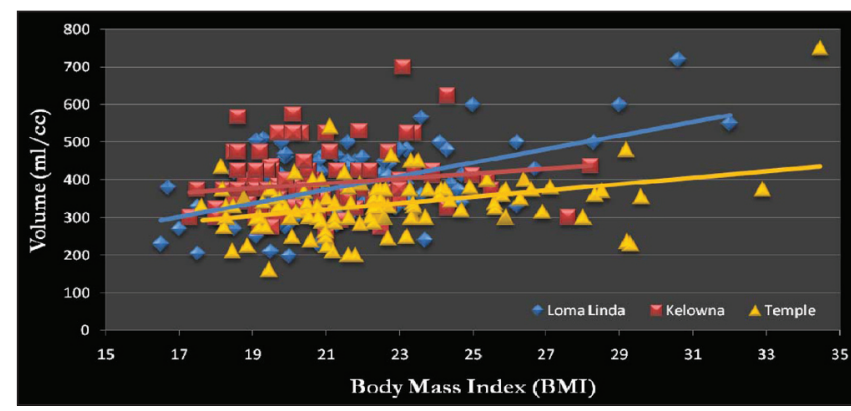

Figure 1) Body mass index versus implant volume by site

Kingdom (11). While no inferences can be made on the basis of these limited data, it does raise the interesting possibility that the average breast implant in Denmark and the United Kingdom (and possibly Europe) is smaller than that of North America. Elucidation of reasons for these differences would require further investigation beyond the scope of our study.

The breasts were deemed to be asymmetric in $23 \%$ of cases (as judged by the final implant volume to create symmetry) and the average difference from side to side in our cases was $25.1 \mathrm{~mL}$, with a range of $0 \mathrm{~mL}$ to $60 \mathrm{~mL}$. This finding was expected and consistent with that reported in the literature (12).

Although BMIs and implant volumes were significantly different between the sites, the Pearson correlation coefficient, within each site, determined a statistically significant positive correlation between BMIs and implant volumes in the American patient populations. The higher the patient's BMI, the larger the implant volume used. To our knowledge, this is the first report of any correlation being identified between the two variables in cosmetic breast augmentation patients. Implications from the correlation found in our study include possibly improving implant volume predictions preoperatively, leading to improved efficiency, outcomes and reduced reoperation rates. Tebbetts' High Five Clinical Evaluation process emphasizes quantifiable measurements instead of subjective visual assessment for breast augmentation operative planning (13). The patient's BMI could potentially provide an additional objective data point on which to base operative planning decisions. Further investigation would be required to ascertain whether patients with higher BMIs require more implant volume to reach the patient and surgeon's perceived ideal breast size.

The present study has a few limitations. It was understood that by using the Kruskal-Wallis test and $\mathrm{P}=0.05$, there was an accepted one in 20 risk of a false-positive result, and by not powering the study to investigate a specific question, small differences would 
not be detected. Practice patterns may have accounted for differences observed, and our study may have been limited by investigating only four- to five-surgeon group practices. Also, the demographic numbers, while larger than other studies in the literature, were still too small to be representative of patient populations in the province or state, let alone the country. Much larger numbers of patients and sites would be necessary for broader generalizations. In the future, Tracking Operations and Outcomes for Plastic Surgeons (TOPS) data may prove to be a very powerful tool in the area of research and could possibly facilitate such data analysis (14).

\section{CONCLUSION}

Patients undergoing cosmetic breast augmentation demonstrated physical characteristics that were similar by geographical location with regard to age, height and parity; however, weight, BMI and implant volume varied across the groups. A positive linear correlation between BMI and implant volume was found in the American cohorts.

ACKNOWLEDGEMENTS: The authors thank the surgeons for agreeing to participate in the data collection of this study.

CONFLICT OF INTEREST: The authors have no conflicts of interest to disclose.

\section{REFERENCES}

1. Cook RR, Delongchamp RR, Woodbury M, Perkins LL, Harrison MC. The prevalence of women with breast implants in the United States - 1989. J Clin Epidemiol 1995;48:519-25.

2. Terry MB, Skovron ML, Garbers S, Sonnenschein E, Toniolo P. The estimated frequency of cosmetic breast augmentation among US women, 1963 through 1988. Am J Public Health 1995;85:1122-4.
3. Bondurant S, Ernster V, Herdman R. Safety of silicone breast implants. Committee on the safety of silicone breast implants, division of health promotion and disease prevention.

Washington, DC: Institute of Medicine, National Academy of Sciences, 1999.

4. National Plastic Surgery Procedural Statistics 2008. Arlington Heights, Ilinois: American Society of Plastic Surgeons, 2009.

5. Sarwer DB, LaRossa D, Bartlett SP, et al. Body image concerns of breast augmentation patients. Plast Reconstr Surg 2003;112:83-90.

6. Strom SS, Baldwin BJ, Sigurdson AJ, Schusterman MA. Cosmetic saline breast implants: A survey of satisfaction, breast-feeding experience, cancer screening and health. Plast Reconstr Surg 1997;100:1553-7.

7. Cook LS, Daling JR, Voight LF, et al. Characteristics of women with and without breast augmentation. JAMA 1997;277:1612-7.

8. Fryzek JP, Weiderpass E, Signorello LB, et al. Characteristics of women with cosmetic breast augmentation surgery compared with breast reduction surgery patients and women in the general population of Sweden. Ann Plast Surg 2000;45:349-56.

9. Kjøller K, Hölmich LR, Jacobsen PH, et al. Epidemiological investigation of local complications after cosmetic breast implant surgery in Denmark. Ann Plast Surg 2002;48:229-37.

10. Kjøller K, Hölmich LR, Fryzek JP, et al. Characteristics of women with cosmetic breast implants compared with women with other types of cosmetic surgery and population based controls in Denmark. Ann Plast Surg 2003;50:6-12.

11. Wong M, Moledina J, Park A. A retrospective study examining the socioeconomic backgrounds of women undergoing bilateral breast augmentation at a private independent hospital in the United Kingdom. Aesthetic Plast Surg 2007;31:566-9.

12. Vandenbussche F. Asymmetries of the breast: A classification system. Aesthetic Plast Surg 1984;8:27-36.

13. Tebbetts JB, Adams WP. Five critical decisions in breast augmentation using five measurements in 5 minutes: The high five decision support process. Plast Reconstr Surg 2006;118:35S-45S

14. American Society of Plastic Surgeons. Tracking operations and outcomes for plastic surgeons (TOPS). <www.plasticsurgery.org> (Accessed on September 16, 2009). 